\title{
INVESTMENTS IN RECREATIONAL AND SPORTS INFRASTRUCTURE AS A BASIS FOR THE DEVELOPMENT OF SPORTS TOURISM ON THE EXAMPLE OF SPA MUNICIPALITIES
}

\author{
ANDRZEJ HADZIK ${ }^{1 \mathrm{a}, 2}$, MAŁGORZATA GRABARA ${ }^{1 \mathrm{~b}}$ \\ ${ }^{1}$ The J. Kukuczka Academy of Physical Education in Katowice, \\ Faculty of Sport and Tourism Management, Department of Tourism Economy, \\ Department of Kinesiopsychoprophylaxis and Promotion of Health \\ ${ }^{2}$ WSB Schools of Banking in Chorzów, Department of Tourism and Recreation
}
Mailing address: Andrzej Hadzik, The J. Kukuczka Academy of Physical Education, Department of Tourism Economy, 72a Mikołowska Street, 40-065 Katowice, tel.: +48 32 2075169, fax: +48 322075270 , e-mail: andrzej_hadzik@wp.pl

\begin{abstract}
Introduction. Among the basic conditions for the development of tourism in spa municipalities, investments in different infrastructure, including recreational and sports facilities should be distinguished. The aim of this work was to show the scope and the financing of sports and recreational investments in selected spa municipalities in Poland. Material and methods. The article uses the diagnostic survey method. The surveys were carried out in June 2012 among the representatives of the selected spa municipalities with the use of a specially prepared questionnaire. Results. The municipalities covered in this research declared carrying out investments in recreational and sports infrastructure, most often in football pitches. During the survey the highest number of investments of this type were conducted in Kołobrzeg. Among other recreational and sports projects, one of the most popular was investing in cycling routes. The research on the sources of financing of investments in recreational and sports infrastructure shows that almost all municipalities declared using funds from their own income. Furthermore, most of the analyzed municipalities used resources from the European Union. Other sources of financing were not that popular. Conclusion. In the time of apparent competitiveness and globalization of the spa market, recreational and sports facilities are very important. The authors believe that sports tourism can be one of the forms of health tourism in spas. The conducted research of spa municipalities has proved that:

- major recreational and sports investments covered sports fields, mainly football pitches and cycling routes,

- the primary sources of financing in the analyzed municipalities turned out to be their own income and resources from the EU.
\end{abstract}

Key words: recreational and sports infrastructure, sports tourism, spa municipalities

\section{Introduction}

Among the basic conditions of tourism development, investments in varied infrastructure should be distinguished, which as a certain economic good can provide tourism services [1]. Investments that are expenses aimed at attracting visitors influence the attractiveness of the widely understood tourist product. In addition, investments determine the production or, in the case of tourism, its types and forms.

In this study, the recreational and sports investments in spa municipalities were analyzed - they are particularly important for the development of the active form of sports tourism. The most important creators of this type of investments are spa municipalities. Besides private entities and the others, they are active participants in the process of creating tourist product in spa areas. This justification of the research subject was the basis for determining the aim of the work, which is to show the scope and the financing of recreational and sports investments in selected spa municipalities in Poland. In this work the following research questions were asked:

1. What is the generic scope of investments in recreational and sports infrastructure in the surveyed spa municipalities?

2. What sources of recreational and sports investments financing do the analyzed municipalities use?

\section{Material and methods}

In this work the diagnostic survey method was used. The surveys were carried out in June 2012 among the representatives of the selected spa municipalities. The questionnaire consisted of five questions, mostly closed-open. For the purposes of the article the representatives of the municipality had to specify recreational and sports equipment as well as facilities built in the recent years, including the sources of their financing.

The study covered one municipality with the so-called potential spa status and 13 other spa municipalities, namely:

- mountain: Krynica-Zdrój, Szklarska Poręba (tourist town belonging to the so-called potential spa municipalities);

- mountain foot: Cieplice-Zdrój, Ustroń, Polańczyk (Solina municipality), Świeradów-Zdrój, Rymanów; 
- lowland: Kołobrzeg, Augustów, Solec-Zdrój, Busko-Zdrój, Inowrocław, Ustka, Połczyn-Zdrój.

\section{Results}

All researched municipalities declared, apart from various projects ${ }^{1}$, investments in a variety of sports and recreational infrastructure in the years 2007-2012 (tab. 1).

Among the recreational and sports infrastructure, most municipalities declared investments in various sports fields, especially in football pitches (11 of the 14 surveyed municipalities). In the researched period of time, most investments of this type were carried out in Kołobrzeg - a spa town with the highest num-

Table 1. Investments in sports and recreational infrastructure in the Polish spa municipalities

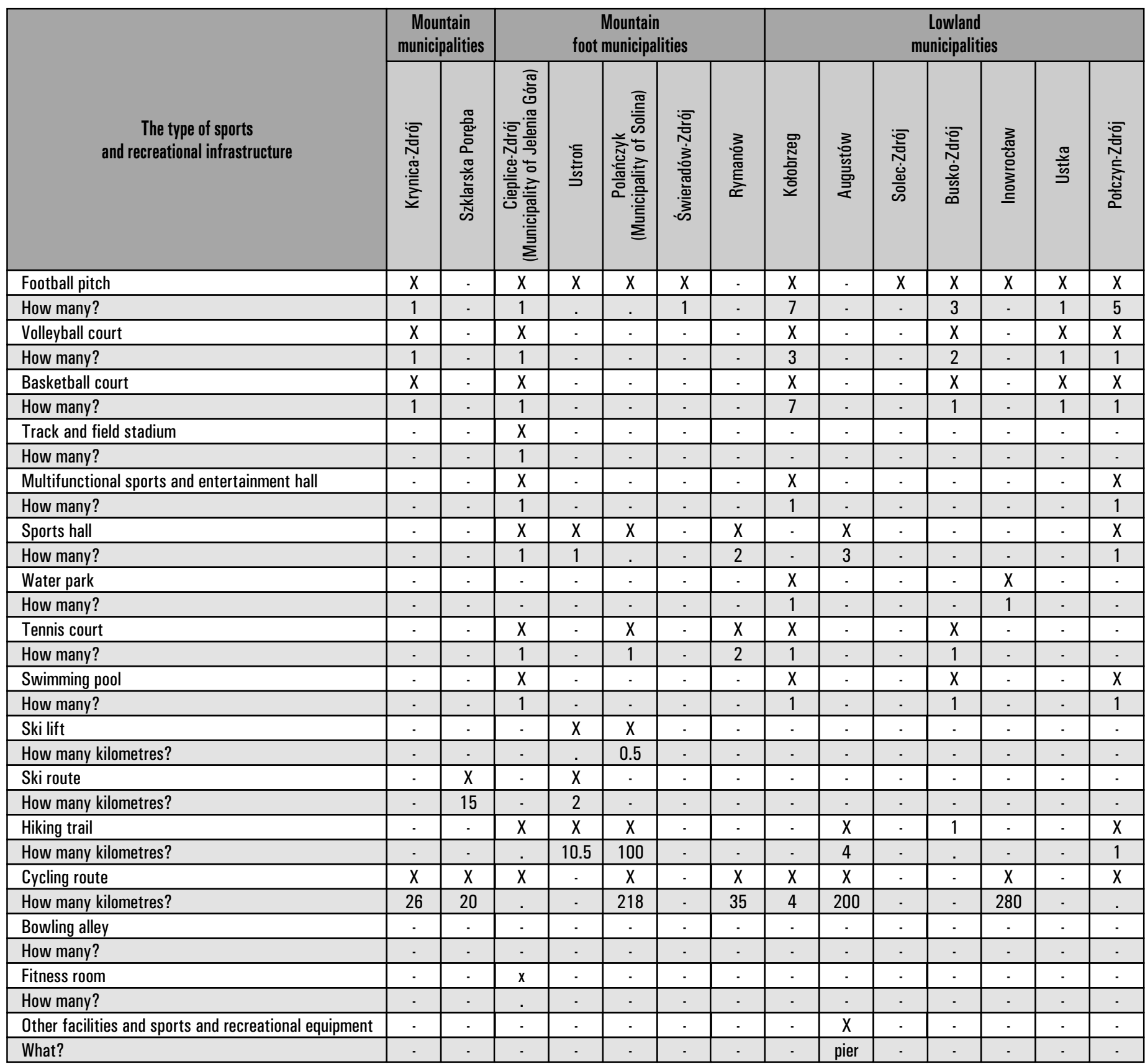

Description:

$\mathrm{X}$ - completed investment in the particular type of sports and recreational infrastructure;

- investment not completed;

- no data in the survey.

Source: own study.

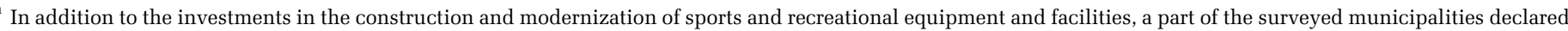

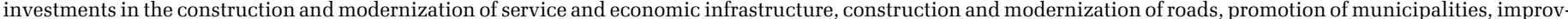

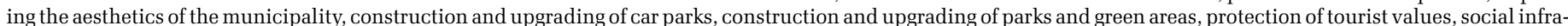
structure, technical infrastructure and so-called non-road, and other investments. 
ber of visitors and tourists among all spas in Poland.

Among other recreational and sports projects, investing in cycling routes proved to be popular, which is a response to the growing popularity of cycling in Poland [2]. In total, the municipalities have declared that their investments involved nearly $800 \mathrm{~km}$ of cycling routes. Among the surveyed municipalities, the biggest investments in this area were made in: Polańczyk, Augustów and Inowrocław. Almost $1 / 3$ of the analyzed municipalities declared investing in hiking trails, which is also a very popular form of recreational physical activity in Poland. In the years 2007-2012 the highest number of kilometres of hiking tracks in the surveyed areas were built in Polańczyk - a spa from Podkarpacie region.

One of the most important investments for the competitiveness of tourism products are swimming pools and water parks. Such recreational and sports investments during the researched period were carried out in $1 / 3$ of the surveyed spa municipalities. This does not mean, however, that in other municipalities there is no such infrastructure. It allows providing recreational and therapeutic services in water, which are attractive to visitors (e.g. hydrotherapy). In some municipalities this type of investments is financed by private sector, for example hotels.

In the years 2007-2012, the investment projects of the surveyed spa municipalities covering recreational and sports infrastructure were financed from various sources (tab. 2).

When analysing the sources of financing of investments in recreational and sports infrastructure, it turned out that almost all researched municipalities, with the exception of Krynica, used funds from their own income. In addition, most of the analyzed municipalities (9 out of 14) financed their investments from the European Union funds.

Other sources of financing were not that popular. These included: donations (1/3 of the municipalities) and loans (Krynica, Swieradów, Kołobrzeg). None of the municipalities declared such financing sources as: promissory notes, leasing, mixed financing for realizations of joint projects of municipalities, mixed financing for realization of projects under the public-private partnership. The last of the above possible sources of financing are particularly important.

\section{Discussion}

Today, the spa municipalities are places of providing not only forms of health tourism based on the typically therapeutic elements, but also recreational and sports ones. Among the latter there is recreational and sports equipment belonging to the major components of tourism development, especially the sports tourism which become more and more important [3] and can be successfully implemented in spa areas [4].

Despite the fact that sports tourism is recognized in the world literature as one of the most dynamically developing kinds of tourism [5], there is not full compliance on the understanding of the scope of this kind of travelling. In the literature, some attempts to define sports tourism combine the

Table 2. Sources of investments in recreational and sports infrastructure in the surveyed spa municipalities

\begin{tabular}{|c|c|c|c|c|c|c|c|c|c|c|c|c|c|c|}
\hline \multirow[b]{2}{*}{ Sources of financing } & \multicolumn{2}{|c|}{$\begin{array}{c}\text { Mountain } \\
\text { municipalities }\end{array}$} & \multicolumn{5}{|c|}{$\begin{array}{c}\text { Mountain } \\
\text { foot municipalities }\end{array}$} & \multicolumn{7}{|c|}{$\begin{array}{l}\text { Lowland } \\
\text { municipalities }\end{array}$} \\
\hline & 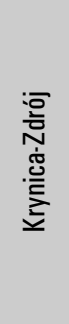 & 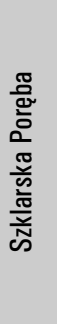 & 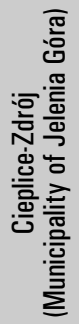 & 㖣 & 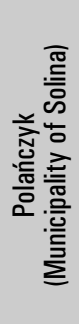 & 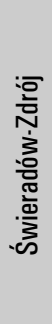 & & $\begin{array}{l}\text { ్ㅠㅁ } \\
\text { 흠 } \\
\text { 훙 }\end{array}$ & 兑 & 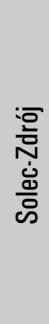 & 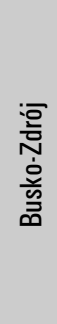 & 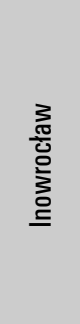 & 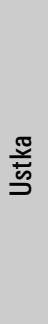 & 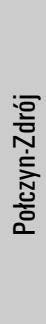 \\
\hline Own income & . & $X$ & $x$ & $\mathrm{X}$ & $x$ & $X$ & $X$ & $x$ & $\bar{x}$ & $X$ & $\bar{X}$ & $\bar{X}$ & $x$ & $X$ \\
\hline Bank loans & $\mathrm{X}$ & - & - & - & - & $x$ & $\cdot$ & $\mathrm{X}$ & - & . & - & - & $\cdot$ & - \\
\hline Donations & . & . & $\mathrm{X}$ & $\cdot$ & $x$ & $X$ & $\cdot$ & $\mathrm{X}$ & - & $X$ & $\cdot$ & - & $\cdot$ & - \\
\hline Non-repayable funds from UE & $\mathrm{X}$ & $\mathrm{X}$ & $\bar{X}$ & $\mathrm{X}$ & $X$ & $\cdot$ & $\bar{x}$ & $\mathrm{X}$ & $\bar{X}$ & $\cdot$ & $\bar{X}$ & $\cdot$ & $\cdot$ & $\cdot$ \\
\hline Loans & - & - & - & $\cdot$ & - & $\cdot$ & $\cdot$ & $\cdot$ & - & - & $\cdot$ & - & $\cdot$ & - \\
\hline $\begin{array}{l}\text { Mixed sources of financing - } \\
\text { joint inter-municipal projects }\end{array}$ & - & . & . &. & . & . &. & . & - & - & . & - & . & - \\
\hline Municipality bonds & $X$ & . & - & $\cdot$ & - & $\cdot$ & - & - & $x$ & . & - & - & $\cdot$ & . \\
\hline Grants & $\cdot$ & $\cdot$ & - & - & - & - & $\cdot$ & $\mathrm{X}$ & - & - & $\cdot$ & - & $\cdot$ & $\cdot$ \\
\hline $\begin{array}{l}\text { Mixed sources of financing - } \\
\text { projects of the public-private partnership }\end{array}$ & - & . & - & - & - & - & - & . & - & - & - & - & - & - \\
\hline Promissory notes & - & - & $\cdot$ & $\cdot$ & $\cdot$ & $\cdot$ & $\cdot$ & $\cdot$ & - & . & - & - & $\cdot$ & $\cdot$ \\
\hline Leasing & . & . & - & $\cdot$ & - & $\cdot$ & $\cdot$ & - & - & - & - & . & $\cdot$ & . \\
\hline Other sources of financing & $\cdot$ & - & - & - & $X$ & - & $\cdot$ & . & 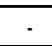 & . & . & $X$ & . &. \\
\hline (What?) & - & - & $\cdot$ & $\cdot$ & $\begin{array}{l}\text { MST } \\
\text { funds }\end{array}$ & $\cdot$ & - & & & - & - & 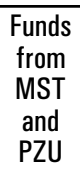 & $\cdot$ & $\cdot$ \\
\hline
\end{tabular}


term "sport" and "tourism" leading to the definition of "sport outside the house", which is defined as "...all forms of active or passive participation in sports, both competitive and amateur, recreational or for commercial purposes, which require travel outside the place of residence and work" [6].

In the context of sports tourism, Kurek includes recreational and sports infrastructure [7] to the additional segment, as part of tourism development, and defines it as “...sports and recreational facilities in the area of the tourist reception, which allow tourists to practice various forms of recreation associated with e.g. skiing, water sports or spending leisure time in the form of fun and entertainment”. Recreational and sports infrastructure, from the point of view of health and sports criteria, can be divided into: purely sports infrastructure for organizing sports events and recreational infrastructure for practising physical activity for health reasons. The work focuses on the analysis of investments in recreational and sports infrastructure in spa municipalities for practicing physical recreation for health, aside from the area of passive forms of sports tourism, that is travelling in order to participate in sports events. Thus for the studies of recreational and sports investments the following infrastructure was distinguished: sports fields for team sports, water parks, tennis courts, swimming pools, ski lifts, ski runs, trails and routes for hiking and biking.

A similar division can be found in literature. For example, Kowalczyk, Derek [3] divide the recreational and sports facilities into: indoor swimming pools, bowling alleys, saunas and outdoor recreational and sports equipment (outdoor swimming pools, sports fields, areas for playing golf, riding, fitness trails, equipment for winter sports and others). The national literature includes the concept of "physical resources for physical culture", which can be regarded as a synonymous of the term "recreational and sports infrastructure", into which Ryba [8] includes financial resources, facilities, sports equipment and devices.

Analyzing foreign literature, one of the most important concepts of infrastructure for the development of sports tourism is a proposal of Standeven and De Knop [9], who, under the socalled recreational and sports facilities distinguish: marinas (harbours), golf courses, skating rinks, sports fields, swimming pools, climbing walls, leisure centres, ski lifts, tennis courts, regatta tracks, bowling facilities and others.

Among the above mentioned types of facilities, in the research period the municipalities invested primarily in various sports fields and all kinds of cycling routes. This is partly caused by the demand. Indirectly, it is suggested by the results of representative surveys of GUS (Central Statistical Office), which show that in Poland households mainly own such equipment as: bikes (almost $71 \%$ of the respondents) and balls for team games (more than $37 \%$ of the respondents) [2]. It should be remembered that cycling is the most popular form of recreational physical activity. $66 \%$ of Poles declare practising recreational cycling [2]. According to GUS practising team sports is also popular (recreational football is declared by more than $20 \%$ and volleyball by nearly $14 \%$ of Poles).

Researches of Polish spas confirm that nowadays, such motivations as "trips to the waters" do not only apply to therapeutic and rehabilitation aims, but also to preventive aim associated with physical recreation which is increasingly important for many travellers $[10,11,12]$. This is important, because the implementation of the preventive aim in spas can be done through the use of different kinds of recreational and sports offer, including forms of physical recreation. However, the proper investments and financing of recreational and sports infrastructure are necessary. Despite a large number of recreational and sports investments in the surveyed spa municipalities, infrastructure deficiencies could be noticed when it comes to recreational swimming pools (only 4 municipalities declared this type of investments) and water parks (2 municipalities). It should be remembered that this type of investments, including geothermal ones, improve the attractiveness of the spa product, and thus have a positive impact on the competitiveness of spa municipalities. Despite the fact that Poland has areas with geothermal resources, their "deep" localization of over 2 thousand meters below ground level cause that this type of investments are very expensive. Hence, geothermal investments made in recent years (the first thermal spa in Poland in Uniejów, geothermal parks in Bukowina, Białka Tatrzańska and Szaflary) are not still sufficiently noticed in Poland.

The elimination of the above mentioned deficiencies is important in the context of improving the competitiveness of the spa municipalities. It should be remembered that, for example, thermal pools infrastructure can be found in many tourist destinations in the Czech Republic and Slovakia. These places often combine services of thermal pools with an excellent infrastructure for ski tourism and mountain hiking, becoming very serious competitors for the Polish health spas on the market of not only foreign, but also Polish tourists. However, investing in such facilities requires various sources of financing. Researches have shown that spa municipalities use mainly funds from their own income, which makes it difficult for them to finance expensive projects, including the above mentioned geothermal investments. Municipalities declare using the European Union funds, but do not use mixed funding opportunities when implementing joint projects within the framework of inter-municipal and public-private partnerships. This is especially important due to the greater possibility of creating complex tourist product of the area, the creators of which are often not one, but two or more municipalities, and not only the public, but primarily private entities with which municipalities should enter into all sorts of so-called business partnerships.

\section{Conclusions}

The authors believe that when it comes to health tourism in spas, the sports tourism can be one of their forms, together with typically medical (therapeutic) tourism. The conducted research of spa municipalities has shown that:

- major recreational and sports investments were sports fields, mainly football pitches and cycling routes,

- the primary sources of financing in the analyzed municipalities turned out to be their own income and resources from the EU.

If national spa municipalities want to get a sustainable competitive advantage over foreign resorts, they should constantly offer newer services, often based on investments in recreational and sports infrastructure innovations. Such innovations allow not only to meet the expectations of today's "difficult" tourists, but also to overcome them, so the visitors could be more satisfied with the offer, allowing the spa municipalities to find their loyal customers.

\section{Literature}

1. Panasiuk A. (2011) Tourism and recreation management and administration. Warszawa: Wydawnictwo Naukowe PWN. [in Polish]

2. Central Statistical Office. (2013). Participation of Polish people in sport and physical recreation in 2012. Warszawa: GUS. [in Polish]

3. Kowalczyk A., Derek M. (2010). Tourism infrastructure. Warszawa: PWN. [in Polish]

4. Spivack E. (1998). Health spa development in the USA: A burgeoning component of sport tourism. Journal of Vacation Marketing 4(1), 65-77. 
5. Bidiscombe R. (2007). Creating successful strategies in sport tourism. London: Sport Business Group.

6. Weed M.E., Bull C.J. (2009). Sports tourism: Participants, policy $\&$ providers ( $2^{\text {nd }}$ ed.). Oxford: Elsevier.

7. Kurek W. (2007). Tourism. Warszawa: PWN. [in Polish]

8. Ryba B. (2000). Fundamentals of organisation and management of sports institutions. Warszawa: Polska Korporacja Menedżerów Sportu, Biblioteka Menedżera Sportu. [in Polish]

9. Standeven J., De Knop P. (1999). Sport tourism. Champaign Human: Kinetics.

10. Burzyński T. et al. (2005). Factors influencing quality and competitiveness of tourist services in spa towns. KrakówKrynica: Instytut Turystyki w Krakowie Sp. z o.o., Stowarzyszenie Gmin Uzdrowiskowych RP. [in Polish]
11. Hadzik A., Kantyka J., Szromek A. (2009). Health tourism and wellness as modern forms of Spa tourism. In J. Bergier (Ed.), Wellness and success (pp. 97-112). Lublin: NeuroCentrum.

12. Górna J. (2011). Determinants and development trends of spa services in Poland, considering integration with the European Union. Doctoral thesis. Politechnika Częstochowska, Częstochowa. [in Polish]

Submitted: March 20, 2014

Accepted: April 22, 2014 